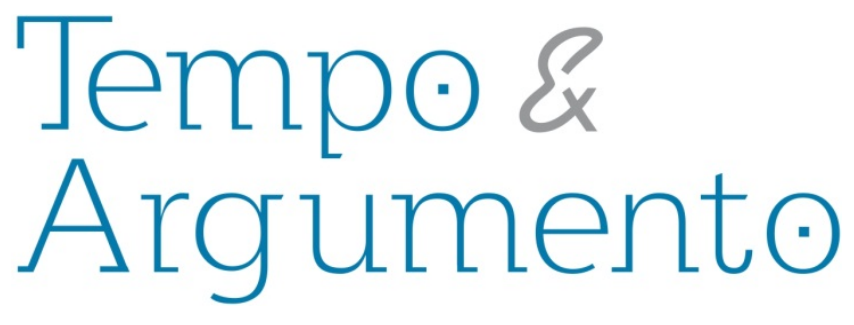

\title{
La fiesta peronista: recorridos y apropiaciones entre fotografía, arquitectura efímera y poder político
}

\begin{abstract}
Resumen
El objetivo de este trabajo es analizar la relación entre algunos de los escenarios, fotografías y afiches utilizados como parte de las estrategias de propaganda desarrolladas por el aparato de administración peronista y explicar su incidencia en la Fiesta de la Vendimia y su construcción imaginaria en torno de la "nueva Argentina" después de la Segunda Guerra Mundial. En este momento histórico particular, los registros gráficos y fotográficos considerados son una puerta de entrada para el análisis de los fenómenos efímeros que no pueden ser recuperados de otro modo. La estrategia metodológica utilizada es cualitativa y de tipo exploratorio, con un diseño de carácter flexible. Si bien estos testimonios, reflejados en las fuentes descriptas, no nos devuelven la posibilidad de estar en contacto directo con esas experiencias, sino que nos permiten acceder al conjunto de deseos, tensiones, frustraciones, expectativas, debates, los éxitos y los fracasos mediante los cuales se formularon y desarrollaron los proyectos de arquitectura escénica y propaganda política.
\end{abstract}

Palabras clave: Archivos fotográficos; Arquitectura Efímera; Fiesta de la Vendimia; Relaciones de Poder; Peronismo.

\section{Franco Marchionni Sánchez}

Doctor en Arquitectura por la Universidad de Mendoza. Magíster Arte Latinoamericano por la Universidad Nacional de Cuyo. Es Investigador

Adjunto del Consejo Nacional de Investigaciones Científicas y Técnicas CONICET | IADIZA Argentina.

fmarchionni@mendoza-conicet.gob.ar

\section{Para citar este artículo:}

MARCHIONNI SÁNCHEZ, Franco. La fiesta peronista: recorridos y apropiaciones entre fotografía, arquitectura efímera y poder político. Tempo e Argumento, Florianópolis, v. 8, n. 17, p. 180 - 214, jan./abr. 2016. 
The Peronist festival: pathways and appropriations between photography, ephemeral architecture and political power

\begin{abstract}
The aim of this paper is analyzing some of the scenarios, photos, and posters used by the Peronist administration and explain their incidence in wine festivals and their imaginary construction after World War II. This proposal examines the relation between photography and ephemeral architecture mediated by political power, as a part of the strategies developed by the Peronist propaganda apparatus to feed the imaginary surrounding the 'New Argentina.' At this particular historical moment, the graphic and photographic records taken into account are a gateway to analyze the ephemeral phenomena that cannot be resumed otherwise. The methodological strategy used is qualitative and exploratory, and its design has a flexible nature. Although these testimonies, reflected in the sources described, do not give us back the possibility of being in direct contact to these experiences, they do allow us to access the set of desires, tensions, frustrations, expectations, debates, the achievements and failures, through which the scenic architecture projects were formulated and developed.
\end{abstract}

Keywords: Photographic Archives; Ephemeral Architecture; Harvest Festival; Power Relationships; Peronism.

\section{A festa peronista: caminhos e apropriações entre fotografia, arquitetura efêmera e poder político}

\begin{abstract}
Resumo
O objetivo deste trabalho é analisar alguns dos cenários, das fotografias e dos cartazes utilizados pelo governo peronista e explicar sua incidência nas festas da uva e sua construção imaginária após a Segunda Guerra Mundial. Esta proposta analisa a relação entre a fotografia e a arquitetura efêmera mediada pelo poder político, como parte das estratégias desenvolvidas pelo aparato de propaganda peronista para alimentar o imaginário acerca da "Nova Argentina". Nesse momento histórico específico, os registros gráficos e fotográficos considerados são uma porta de entrada para a análise dos fenômenos efêmeros que não podem ser recuperados de outra forma. A estratégia metodológica utilizada é qualitativa e exploratória, com desenho de natureza flexível. Embora esses testemunhos, refletidos nas fontes descritas, não tragam de volta a possibilidade de estar em contato direto com essas experiências, proporcionam acesso ao conjunto de desejos, tensões, frustrações, expectativas, debates, os sucessos e os fracassos, por meio do qual os projetos de arquitetura cênica e propaganda política foram formulados e desenvolvidos.
\end{abstract}

Palavras-chave: Arquivos Fotográficos; Arquitetura Efêmera; Festa da Vendimia; Relações de Poder; Peronismo. 


\section{Archivos de poder, el poder de los archivos}

En general, los historiadores han preferido la reconstrucción del pasado sobre la base de textos y documentos escritos, datos políticos, económicos, sociales y estadísticos. También han utilizado, en algunos casos, los testimonios orales. Pero ¿cómo sería la historia del fascismo, del stalinismo o -concretamente del peronismo- si no hubiéramos conocido las imágenes usadas por sus aparatos de propaganda?

Resulta entonces un enorme desafío reflexionar sobre el lugar de la imagen en la producción científica de las ciencias sociales y analizar su uso como herramienta privilegiada de conocimiento; y es particularmente importante plantear este desafío en contextos latinoamercanos. Aquí nos interesa rastrear sus formas y lenguajes y reconocer las posturas teórico-metodológicas sobre las que se basan sus usos. También pretendemos analizar la relación entre imagen y mensaje como un modo de expresión y preservación, difusión y utilización de memorias personales, sociales y políticas.

Todos acordamos en que tanto la memoria como la historia tienen sus raíces en los archivos. Es más, podemos afirmar igualmente que esas raíces también están en imágenes. Sin estos testimonios, la memoria estaría incompleta, los acontecimientos idos ignorados, el orgullo de un pasado común disipado. Los registros considerados en este trabajo pretenden compensar esos desbalances, y para ello consideramos la fotografía como medio e instrumento adecuado y preciso para tal rescate, pues creemos que este es especialmente pertinente en el mundo contemporáneo.

En los últimos años, el concepto "archivo" ha experimentado un resurgimiento -más allá de su connotación popular asociada a sótanos oscuros y polvorientos o papeles ajados y amarillentos- fundamentalmente en los estudios culturales. Teóricos de la cultura, sobre todo Michel Foucault y Jacques Derrida, ven el archivo como una construcción metafórica en la que anidan perspectivas sobre el conocimiento humano, la memoria, las relaciones de poder y la búsqueda de la justicia (Schwartz and Cook, 2002). 
Así los archivos asumen la tarea de privilegiar o marginar diversos modos de ver entendiendo este último concepto como un modo de conocimiento- pueden constituirse en un instrumento hegemónico o en una herramienta de resistencia. En ambos casos reflejan y constituyen distintas relaciones de poder. De accuerdo con la opinión de Schwartz and Cook, ellos son la base y la validación de las historias que nos contamos a nosotros mismos, de los relatos políticos, de los relatos que dan cohesión y sentido a los individuos, los grupos y las sociedades. Los archivos entonces constituyen poderosos instrumentos para controlar lo que en el futuro se va a conocer del pasado. En consecuencia, debemos estar preparados para responder a los desafíos impuestos por el mundo contemporáneo y preservar su existencia y uso.

La consideración del repertorio de imágenes, fotografías, afiches y escenografías visitadas en esta propuesta, que damos en llamar la fiesta peronista, nos estimuló a observar el ejercicio de poder de los distintos actores involucrados en el diseño de lo que simbólicamente representó "un nuevo país", proyecto político desarrollado con una dinámica avasalladora entre el 1943 y el abrupto fin del segundo mandato constitucional de Juan Domingo Perón, en 1955.

Para comprender la relación archivo-poder cabalmente, en su escala e intensidad en el contexto histórico del peronismo, se hace necesario reparar en aquellos que alimentaron y sostenieron esa relación. Raúl Apold ${ }^{1}$ fue el encargado de las comunicaciones del régimen peronista en Argentina entre 1946 y 1955. Quizás este funcionario de bajo perfil haya sido la persona más poderosa del régimen después de Juan y Eva Perón. "Apold es el secreto mejor guardado en el peronismo" declara Mercado, S. D. (p. 11). Los registros históricos señalan a Apold como el responsable de convencer a Perón de renombrar a su organización Partido Peronista a fines del 1946 (pp. 101-103). También se sostiene que este funcionario construyó desde el Estado el

\footnotetext{
${ }^{1}$ La trayectoria profesional de Raúl Apold antes de 1946 se dividió en distintos roles: dandi, periodista con contactos políticos, representante de artistas de cine y cabildero para los estudios Argentina Sono Film. Su ascenso sigiloso, pero seguro, dentro de la estructura de poder se dio inicialmente como director del diario Democracia (que respondía a Eva Perón) y director de noticieros cinematográficos, como articulador de ALEA, el conglomerado de medios de comunicación del cual Juan Perón era parcialmente propietario y más tarde como director general de difusión entre 1947 y 1949. (Cf.: Mercado, S., 2013, pp. 96-97, 106-107).
} 
En el 1947 Apold había sido promovido a subsecretario de informaciones, ejerciendo su enorme influencia. Fue encargado entonces de implementar la estrategia oficial para controlar los medios de comunicación: la confiscación de papel prensa, la compra de radioemisoras con fondos reservados, la nacionalización del diario La Prensa y el exilio interno de artistas y escritores. Era tal el poder ejercido por Apold a través de la Dirección de Asuntos Especiales que, con corresponsales en todo el país, funcionaba como una red de inteligencia para informar al presidente sobre la lealtad de sus funcionarios (Luna, F., 1984, 1985; Mercado, S. D., 2013).

Conocer el perfil de Apold, en este contexto, ofrece una ventana para observar procesos históricos más amplios: el ascenso de Perón y su caída, las facetas menos democráticas de su régimen y fundamentalmente los mecanismos históricos de control de la prensa, la comunicación, la difusión, el cine, la televisión, la radio y por supuesto la fotografía que contribuyeron a esa construcción imaginaria del peronismo. Su poderosa acción al interior del movimiento político fundado hace casi siete décadas acoge, junto a su historia más autoritaria, una poderosa tradición que cuestiona la verticalidad cultural y la pretensión hegemónica de cualquier discurso construido desde el Estado (Ballent, A., 2005; Gené, M., 2005; Lobato, M., 2005; Luna, F., 1984; Marchionni, F., 2008, 2012a, 2012b; Mercado, S. D., 2013; Pérez-Liñán, A., 2013).

A partir del análisis de imágenes y consignas utilizadas por el aparato de propaganda peronista, se intentó reconstruir la mirada que mostró la acción deliberada del peronismo por alimentar el imaginario en torno de la "nueva Argentina", imagen que también se replicó en el contexto de las fiestas regionales en el interior del país (Marchionni, F., 2012b, 2013). En este sentido, este trabajo no solo presenta un estudio histórico riguroso, sino que intenta reconocer de qué modo el peronismo se apropió y resignificó la Fiesta de la Vendimia a través de una lectura del patrimonio efímero plasmado en los fondos gráficos y fotográficos oficiales. 
El abordaje de esta labor está planteado a partir de la consideración de la fotografía como fuente documental para la investigación histórica, y se desarrolla tributando en las categorías desarrolladas por Moscovici, Jodelet, Silva y Baczko sobre el concepto de representación social. Este concepto se define como el modo de producción cognitiva que corresponde a una persona y grupo en un contexto sociohistórico determinado. Suponemos que las fotografías, miradas desde la disciplina histórica, son documentos valiosos que contribuyen al conocimiento histórico y pueden funcionar como testimonios de la evolución temporal de las sociedades. Sin embargo, para que resulten útiles como testigos de un tiempo ido, han de ser vinculadas, especialmente en nuestro caso, a coordenadas sociopolíticas para alcanzar una lectura completa de esa imagen particular. Todavía, debemos destacar que no se trata de un problema de registro, sino de interpretación y explicación de la fiesta como producto cultural. De este modo, resulta importante la dimensión espacial y artística en tanto actúa como emisor de mensajes plausibles de ser examinados.

\section{Estrategia y posicionamiento}

La estrategia metodológica utilizada es cualitativa y de tipo exploratoria, con un diseño de naturaleza flexible (Vallés, 2000). Suponemos que el repertorio de imágenes, fotografías, afiches y escenografías interpeladas desde la historia son documentos valiosos que condensan mensajes explicativos de su propia génesis y contexto sociohistórico. La combinación de estas fuentes con el análisis de los discursos propagandísticos contenidos en el relato peronista (Ballent, A., 2005; Gené, M., 2005; Lobato, M., 2005; Luna, F., 1984, 1985, 1986; Marchionni, F., 2008, 2012a, 2012b, 2013) y la lectura y reflexión de la bibliografía pertinente nos permitió conformar el análisis histórico del repertorio gráfico y fotográfico seleccionado. Se profundizó, de acuerdo con la información disponible en cada caso, en la relación existente entre los aspectos formales adoptados para la resolución de estos dispositivos de propaganda y el proceso constitutivo de los imaginarios sociales consolidados a partir de discursos políticos, prácticas sociales y valores circulantes en la sociedad del período temporal consignado. 
La clave de este trabajo en el análisis de las fotografías de los escenarios de fiestas y festivales, de propagandas y afiches, es justamente la idea de analizar y reflexionar sobre imágenes de sucesos y objetos (pósters) efímeros. La apuesta diferencial de esta proposición se apoya en considerar situaciones pensadas desde su concepción para provocar un efecto determinado, pero no para ser valoradas desde la perspectiva material, puesto que no es una condición intrínseca a los dispositivos analizados. Ese es el desafío al que hacemos frente y, a la vez, el matiz más brillante de esta labor.

Con una eficaz declaración de posicionamiento y esta metodología, intentamos historiar los sucesos abordados, suponiendo que las fotografías como la gráfica entendidos como fenómenos técnicos-, son condicionadas sociopolíticamente y permanecen sujetas a un determinado discurso de poder. Esa ideología -de las estructuras de poder y de quienes empuñaban la cámara- se halla subsumida en las imágenes abordadas, por lo que, frente a esta situación, nos propusimos descifrar la información cultural contenida en esos documentos. ${ }^{2}$

\section{Discusión}

Partiendo del acuerdo que supone pensar la memoria como una actividad selectiva, cabe preguntarse ¿qué selección de imágenes y formas operan en la construcción del imaginario en torno de la "nueva Argentina”? ¿Qué relaciones pueden leerse entre los procesos de transformación material y sus representaciones en el plano simbólico? Las preguntas planteadas nos indican claramente que el universo alegórico contenido tanto en la gráfica usada por propaganda política peronista, como en las fiestas regionales a lo largo y ancho del país, no pueden ser abordadas sin entenderlas simultáneamente en sus dimensiones materiales y simbólicas (Lobato, M., 2005). Se busca entonces comprender este doble carácter -las representaciones sociales y los

\footnotetext{
${ }^{2}$ El aporte de los hermanos si bien trabaja un recorte temporal más amplio, condensa una enorme cantidad de testimonios fotográficos relacionados con la Fiesta Nacional de la Vendimia. Quizás es una de las obras más importantes hasta el momento por la cantidad y calidad de los testimonios colectados relacionadas con la fotografía de la fiesta mendocina. Cf.: Sevilla, Ariel y Fabián, 2006. La Vendimia para Ver. 70 años de fiesta en 850 imágenes. Mendoza: Ministerio de Turismo y Cultura-Gobierno de Mendoza.
} 
procesos de transformación material- plasmados tanto en la gráfica como en la arquitectura efímera fundamentalmente durante el primer gobierno peronista.

El análisis propuesto por el recorte de este trabajo retoma la idea de memoria como actividad selectiva basándose en la consideración de seis obras fundamentales: Amaral y Botalla (2010); Gené (2005); Gutiérrez, et al. (2009); Indij (2006); Marchionni (2012) y Sevilla, Ariel y Fabián (2006). Todos estos trabajos comparten la fotografía, la imagen y los fenómenos efímeros como medio para establecer el análisis histórico del imaginario peronista. Además, condensan valiosos testimonios fotográficos de ese particular periodo histórico de Argentina y funcionan como vigilantes y custodios de ese maravilloso patrimonio que da cuenta de las dimensiones efímeras mediadas por la fotografía, abordadas en este trabajo.

Uno de los aspectos emergentes en el análisis de este compendio documental lo constituye el concepto de representaciones sociales; éste es entendido como una reflexión sobre las emergentes visuales de dimensión simbólica que aparecen a lo largo de la historia vendimial. Por lo expuesto acordamos con Moscovici (1979) cuando define las representaciones como estructuras simbólicas encargadas de atribuir sentido a la realidad, así como para definir y orientar comportamientos. En sus palabras las representaciones son

[...] una modalidad particular del conocimiento, cuya función es la elaboración de los comportamientos y la comunicación entre los individuos [...] La representación es un corpus organizado de conocimientos y una de las actividades psíquicas gracias a las cuales los hombres hacen inteligible la realidad física y social, se integran en un grupo o en una relación cotidiana de intercambios, liberan los poderes de su imaginación (pp. 17-18).

Pero las representaciones, como dirá Jodelet (1984), no son simplemente una reproducción de algo, sino más bien una reconstrucción o recreación mediada por la experiencia vital del sujeto en un ámbito cultural determinado donde participa también el imaginario individual o social. La indagación de estas emergentes visuales nos ha permitido -en el recorte temporal propuesto- identificar cuáles son las imágenes populares que el público de esa época reconoce y asume como propias y cuáles son las no 
citadas en esta disputa que resulta de la invención de la Nueva Argentina en el período peronista.

Esta indagación requiere la mediación de la técnica, entendida como gráfica, arquitectura efímera. En otras palabras, para poder indagar las relaciones existentes entre las representaciones sociales y las emergentes visuales de dimensión simbólica, construidas y sustentadas a partir de estos imaginarios, se hizo necesario recurrir, además e la fotografía y la gráfica, a la consideración y al análisis de la escenografía -entendida como arquitectura efímera ${ }^{3}$.

A partir de este planteo acordamos con Gastón Breyer cuando expresa -al referirse al escenario como uno de los objetos primordiales de la arquitectura efímera: "el escenario será soporte de reinscripciones" (2005, p. 18). Desde esta perspectiva, espacialidad y representaciones sociales constituyen dos miradas distintas pero vinculadas en un mismo objeto, las escenografías vendimiales. Así planteada la cuestión, las relaciones entre este binomio y la fiesta estarán mediadas por la técnica. El vínculo entre técnica y representaciones sociales, entonces, será el eje que permitirá abordar campos temáticos amplios -campos cuyo estudio este trabajo no agota, pero de los que da cuenta en sus aspectos sustanciales-, seleccionando objetos dentro de ellos y jerarquizándolos en función de ciertos parámetros de análisis (Ballent, A., 2005; Gené, M., 2005; Lobato, M., 2005; Marchionni, F., 2008, 2012a, 2012b; Sevilla, Ariel y Fabián, 2006; Gutiérrez, R. et al., 2009). En otras palabras, este planteo permitió construir los temas como problemas de la investigación.

La otra noción que nos permitió pensar el rol de los distintos sectores sociales fue la idea de comunidades imaginadas (Anderson, B., 1991) que subyace en el discurso general del Presidente Perón. Este concepto supone que a lo largo de la historia, las sociedades se entregan a una invención permanente de sus propias representaciones globales, otras tantas ideas-imágenes a través de las cuales se procuran una identidad, perciben sus divisiones, legitiman su poder y elaboran modelos formadores para sus

\footnotetext{
3 El análisis propuesto por el recorte de este trabajo se basa en la consideración de seis obras fundamentales ya citadas, que comparten la fotografía, la imagen y los fenómenos efímeros como medio para establecer el análisis histórico del imaginario peronista.
} 
ciudadanos (Baczko, 1991, p. 9). Son aquellas que han demostrado el importante rol que juegan las ficciones -en nuestro caso de análisis materializada por la fiesta-, los imaginarios colectivos, en la formación de las identidades. Este tipo de aproximación tiene consecuencias para la construcción de la ciudadanía cultural, porque esta ciudadanía no se organiza solo sobre principios políticos, según la participación real en estructuras jurídicas o sociales, sino también a partir de una cultura formada en los actos e interacciones cotidianos, y en la proyección imaginaria de estos actos en mapas mentales de la vida urbana (Marchionni, 2012, p. 34).

Entonces nos preguntamos: ¿Qué relación se establece entre el Estado y estas expresiones gráficas? ¿Cómo se usaron estas herramientas comunicativas en relación con las políticas económicas, productivas y culturales del Estado? (Hovarth, L., 1993; Indij, G., 2006; Gené, M., 2005).

En seguida, convenimos en pensar la relación fiesta y Estado preguntándonos: ¿Qué relación se establece entre el Estado y estos fenómenos arquitectónicos efímeros? ¿Cómo se usaron estos dispositivos en relación con las políticas económicas, productivas y culturales del Estado? ¿Cómo se manifestaron en la escenografía vendimial los cambios en el imaginario político y su consecuente representación plástica? (Hovarth, L., Gutiérrez, R. et al., 2009; Sevilla, Ariel y Fabián, 2006).

\section{Nociones, conceptos y proyectos}

Durante la primera presidencia de Juan Domingo Perón (1946-1952), éste junto a José Figuerola -Secretario General del Consejo Nacional de Posguerra- comenzaron a diseñar un plan general de industrialización que incluía medidas para intensificar la producción agrícola, promover la minería, proteger algunas industrias manufactureras, fomentar la investigación, generar estabilidad económica y reactivar la industria de posguerra. En este escenario, el sector industrial de la Argentina había encontrado en esa incipiente apertura mundial una oportunidad particular de crecimiento. 


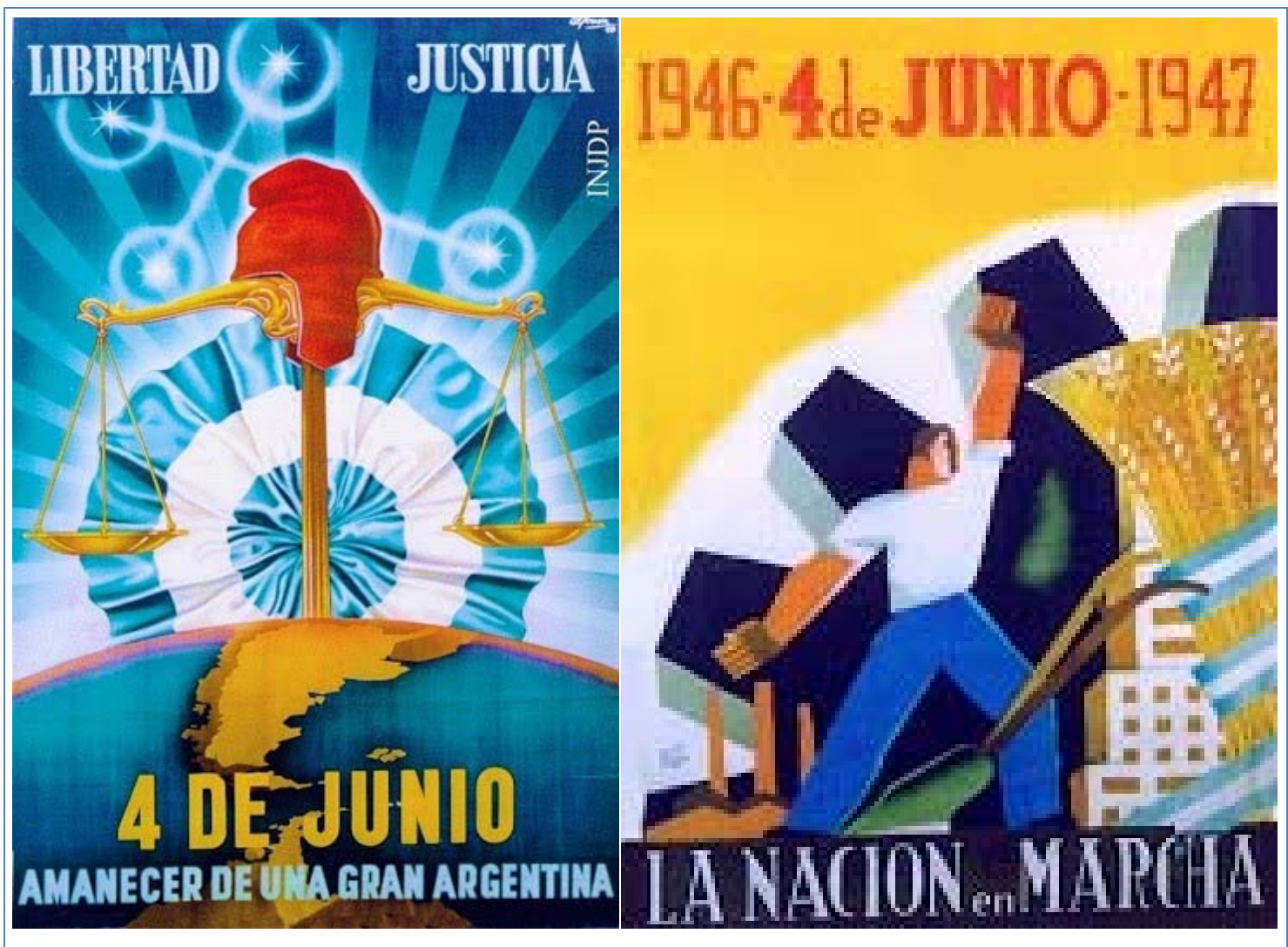

Figura 1: Afiches conmemorativos del primer año del mandato presidencial Perón-Quijano elegida democráticamente el 4 de junio de 1946 | Cartazes comemorativos do primeiro ano do mandato presidencial Perón-Quijano eleito democráticamente em 4 de junho de 1946. (Mosaico gráfico elaborado por el autor. Cortesía del Archivo Gráfico del Instituto Nacional Juan Domingo Perón de Estudios e Investigaciones Históricas, Sociales y Políticas).

El afiche de la izquierda representa el "amanecer de la nueva Argentina" en el cual la escala impuesta en la imagen resulta sideral, cósmica, universal. El centro de la misma está ocupado por una representación de la Argentina continental e insular y su sector antártico. Como contrapunto, aparece al fondo, una enorme escarapela argentina -a modo de Sol de Mayo en forma de Sol Naciente-, la cruz del sur, constelación solo visible desde el hemisferio Sur, y la balanza de la justicia cuyo fiel se encuentra cubierto por un gorro frigio. Completan la composición dos leyendas: en la parte superior "Libertad y Justicia" y en la base: "4 de junio amanecer de una nueva Argentina", fecha conmemorativa del primer año del mandato presidencial Perón-Quijano elegido democráticamente el 4 de junio de 1946.

La composición de la derecha más que a la contemplación apela a la acción. La figura del hombre en el centro del campo compositivo se muestra viril, dinámica y 
vigorosa. Ataviado como un trabajador, ya sea rural o urbano, divide el cuadro señalando a la izquierda y al fondo, silos y chimeneas, y hacia la derecha un manojo de trigo atado con cinta patria. Cierra la composición un arado de mano sobre la leyenda "La Nación en marcha".

Ambas composiciones se destacan elocuentemente por el uso de los colores, el dinamismo compositivo y el poder de sus mensajes. Hacen referencia a momentos históricos distintos: los tiempos preliminares y luego los actuales en los que es posible enfatizar los beneficios del gobierno en funciones luego de su primer año de ejercicio democrático.

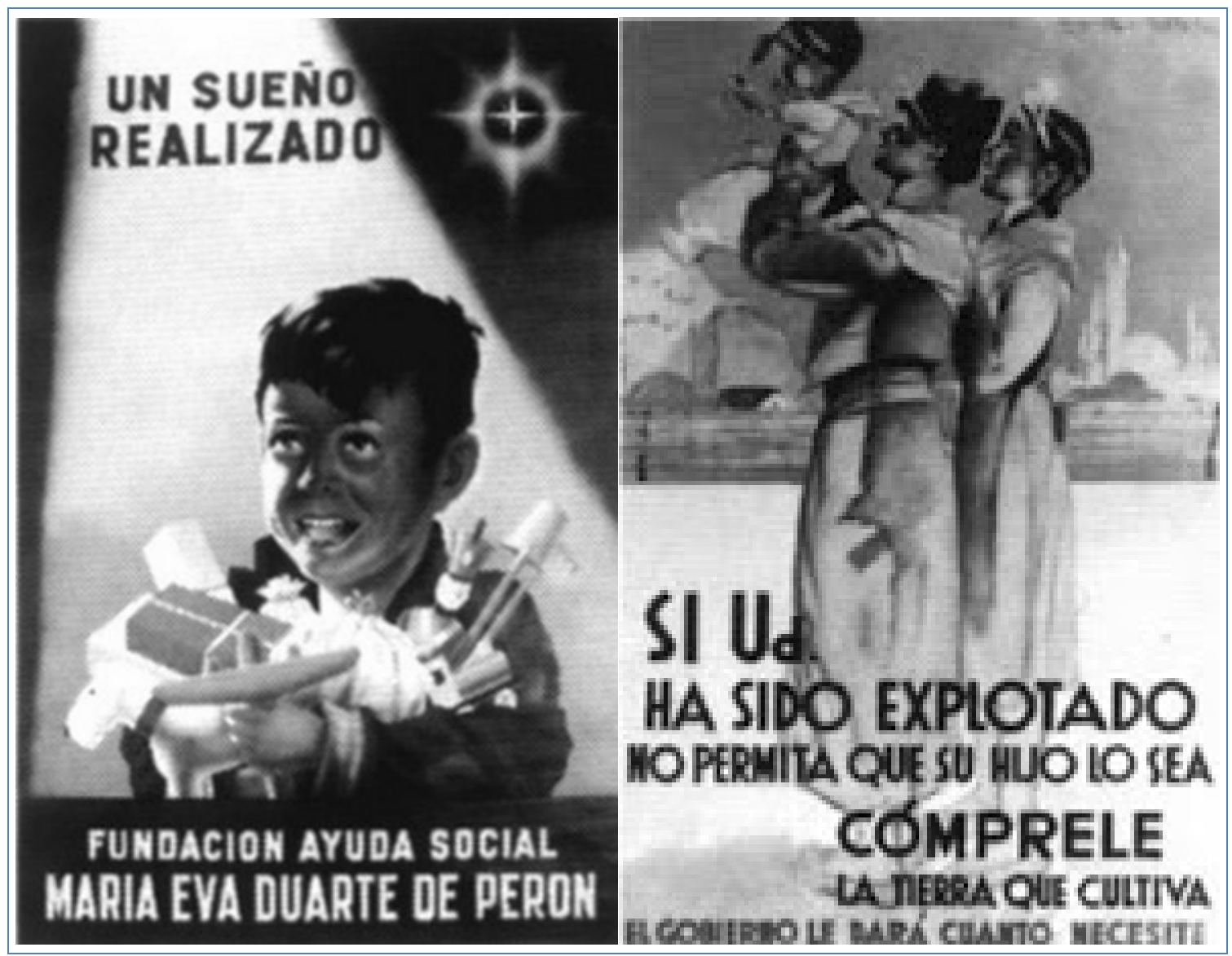

Figura 2: Afiches promocionales de la Fundación María Eva Duarte de Perón | Cartazes divulgando a Fundação Maria Eva Duarte de Perón. (Mosaico gráfico elaborado por el autor. Cortesía del Archivo Gráfico del Instituto Nacional Juan Domingo Perón de Estudios e Investigaciones Históricas, Sociales y Políticas).

La Fundación Eva Perón fue una institución creada por Eva Duarte durante la presidencia de Juan Domingo Perón, con el objetivo de proporcionar asistencia social. La 

sus salarios. Dependiente del Ministerio de Trabajo y Previsión, la fundación distribuía libros, alimentos, ropa, máquinas de coser y juguetes a familias pertenecientes a los sectores de mayor vulnerabilidad social. Mientras vivió, su fundadora se ocupaba personalmente de muchos de sus aspectos e incluso atendía durante horas a las personas que llegaban de todo el país con pedidos de ayuda. La fundación promovió la construcción de policlínicos, escuelas, una Ciudad Infantil, hogares de ancianos, hogares para madres solteras y para jóvenes que llegaban desde las diversas provincias a Buenos Aires para continuar sus estudios o trabajar. También obsequiaba durante las fiestas, presentes como sidra y pan dulce y otros regalos, socorría a los necesitados y organizaba torneos deportivos infantiles y juveniles. El otro bastión y tal vez eje principal de su popularidad lo constituyó su entorno de sindicalistas ligados a la CGT (Confederación General del Trabajo) y su facilidad y carisma para conectarse con las masas trabajadoras a los que ella llamaba sus "grasitas" o "descamisados".

La imagen analizada en este caso apela a dos fuertes aspectos presentes en los grupos sociales de esa época: la niñez y la familia. A la izquierda está presente un niño feliz, cuyos brazos se encuentran colmados de regalos y con su mirada puesta "en lo alto". Se encuentra encuadrado en un cono de luz que lo enmarca y contiene junto a la frase "un sueño realizado". En otras palabras, el dispositivo promueve con eficacia uno de los objetivos de la Fundación María Eva Duarte de Perón, cumplir los sueños de aquellos más desfavorecidos. La imagen de la derecha en el mosaico compositivo invoca la defensa de los derechos -en este caso campesinos-. La composición está dominada por una familia tradicional -hombre, mujer y niño. El padre se encuentra en el centro de la imagen sosteniendo en sus brazos a un pequeño niño que mira hacia adelante. El mensaje escrito es potente; habla de un pasado -el de los adultos presentes en la composición- de injusticia y explotación y pone de relieve las posibilidades que el presente de la nación le otorga a sus habitantes: "No permita que su hijo sea explotado"; "cómprele la tierra que cultiva”; “el Estado le 'dará' canto necesite”. Una particularidad subyacente en el diseño 
de estos afiches es sin dudas el color. La propuesta está organizada en blancos y negros lo que permite inferir que la intención del estado benefactor era la de difundir este tipo de mensaje-propaganda estatal a una mayor escala de distribución que otros.

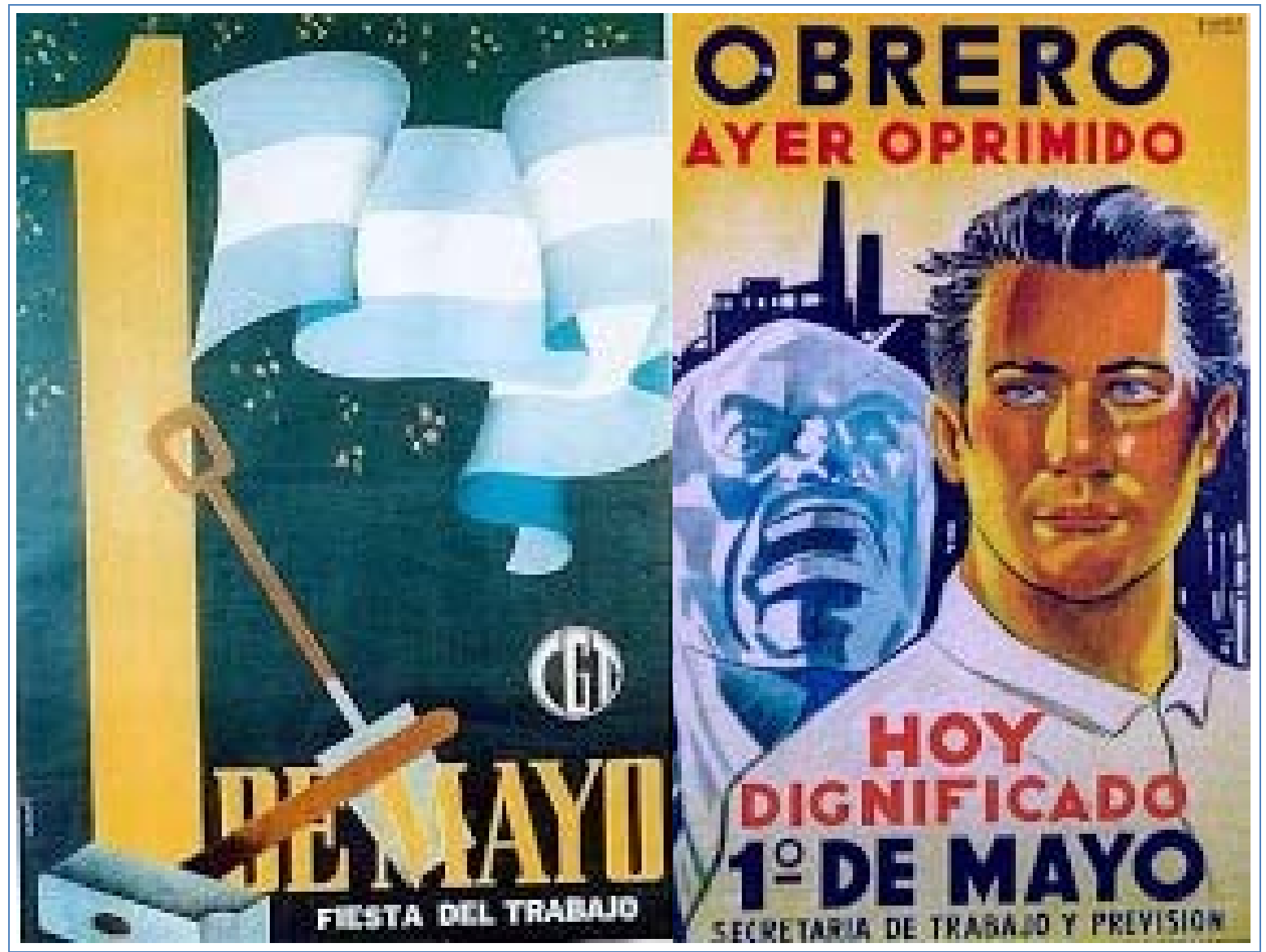

Figura 3: Afiches conmemorativos de la Fiesta del Trabajo | Cartazes comemorativos do Dia do Trabalho. (Mosaico gráfico elaborado por el autor. Cortesía del Archivo Gráfico del Instituto Nacional Juan Domingo Perón de Estudios e Investigaciones Históricas, Sociales y Políticas).

A partir de la asunción a la presidencia de Perón en 1946, las reivindicaciones que los trabajadores habían anhelado se fueron convirtiendo en realidad, y los trabajadores fueron ganando el espacio público, apropiándose de los símbolos y de las significaciones vinculadas al $1^{\circ}$ de mayo. El 1946 fue el primer año en que autoridades nacionales -Juan Domingo Perón, María Eva Duarte y el Secretario de Trabajo y Previsión- encabezaban la movilización. Esa fue la primera ocasión en que el presidente Perón asoció la fecha con el emergente movimiento peronista, y la Confederación General del Trabajo enfatizó que se trataba de un "día de sana alegría y verdadero descanso del músculo". En el folleto " $1^{\circ}$ de 
mayo ayer y hoy" publicado en el 1949 se expresaba claramente una ruptura con el pasado:

[...] El $1^{\circ}$ de mayo no es ya la fecha propicia al dolor y la desgracia, sino a la alegría. La Fiesta del Trabajo, realizada jubilosamente por quienes trabajan en la edificación de la Patria. (Perón, 1949).

A partir del $1^{\circ}$ de mayo de 1947 las características variaron sustancialmente, porque fue la primera celebración bajo el gobierno peronista. El programa de festejos fue en esos años más o menos similar: comenzaba con un discurso del secretario general de la CGT, otro de Evita y culminaba con la palabra de Perón. Luego se presentaban números artísticos en los que intervenían figuras populares (Hugo del Carril, Antonio Tormo, Hermanos Ábalos) y tras un gran desfile de carrozas se elegía la Reina del Trabajo. Los opositores (socialistas y comunistas, entre ellos) debían recordar la fecha en días anteriores y en actos que solo eran permitidos fuera del radio céntrico (Marchionni, F., 2012).

En este tercer mosaico compositivo se comunica la resignificación del día del trabajo en la nueva Argentina. Hay presentes apelaciones al trabajo urbano conjuntamente con el trabajo rural en un contexto "festivo". El $1^{\circ}$ de mayo ahora "es" una fiesta. En esa misma dirección y en forma simple y directa -en la imagen de la derecha- se hace referencia a un pasado de opresión y se ensalza un presente dichoso y reivindicado por la "dignidad”. También se juega con los colores, en este caso los colores grises/sombríos atribuidos al pasado contrastan con la profusión de colores vivos concentrados, sobre todo, en la representación del obrero de hoy, seguro de sí mismo, esperanzado y comprometido en la empresa que implicaba "la nueva Argentina”.

\section{Argentina en marcha, 1951}

En esa misma línea y con la voluntad explícita de hacer visible la obra y legado del peronismo se montaron sistemáticamente a lo largo y ancho del país distintas muestras, festivales y fiestas en clave efímera. La exhibición "Argentina en marcha” consistió en generar una instalación urbana efímera sobre buena parte de la calle Florida, en la imagen 
de abajo, el boceto de la entrada, de la mano del autor -Sabaté- y un croquis particular de la propuesta.

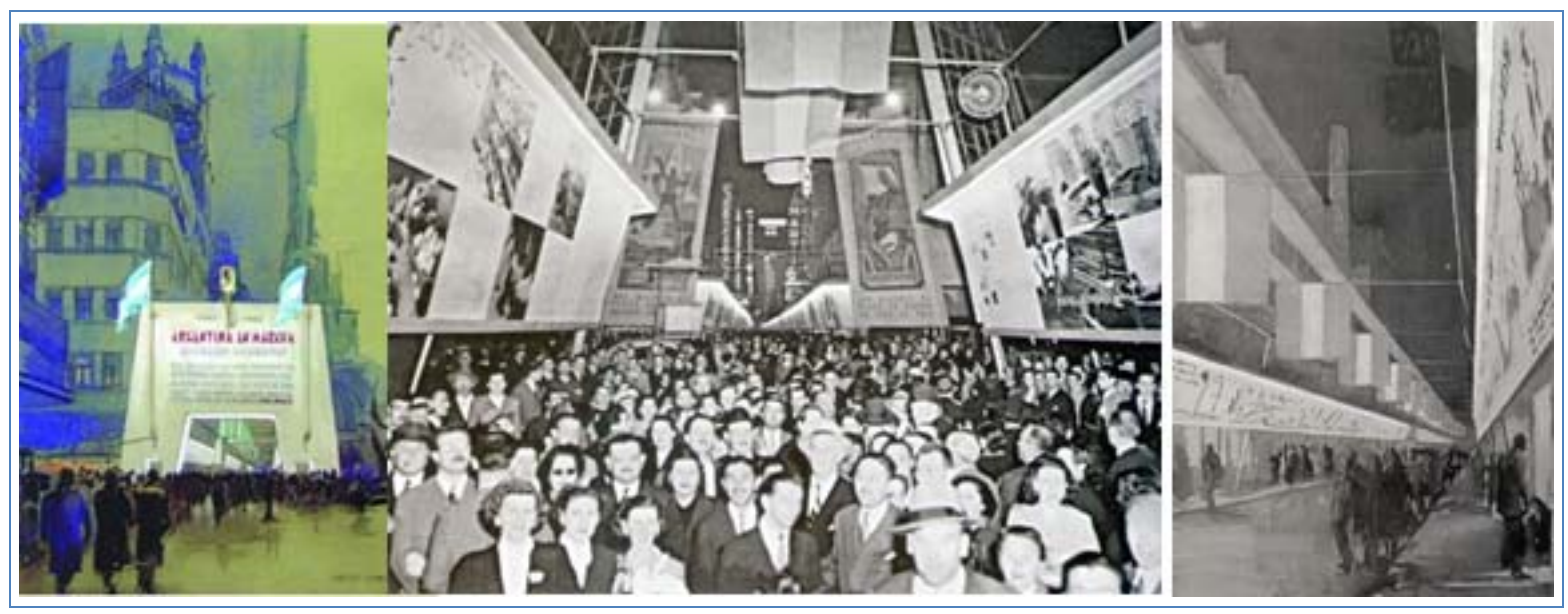

Figura 4: Croquis de proyecto y fotografía de la Muestra Nacional "Argentina en marcha" | Esboço do projeto e fotografía da Amostra Nacional “Argentina em marcha” (Mosaico gráfico elaborado por el autor. Cortesía del Archivo Gráfico del CEDODAL y del Instituto de Inv. Hist. Eva Perón. Edición y corrección de imagen: Augusto Marchionni).

\section{El Festival Internacional de Cinematografía de Mar del Plata 1954}

En el 1954 se llevó a cabo la primera edición de dicho festival, organizado por iniciativa del entonces Subsecretario de Informaciones y Prensa, Raúl Alejandro Apold. Realizado entre el 8 y el 14 de marzo, dicha edición no fue competitiva, sino una muestra en la que se resaltó el cine como espectáculo y con la que se buscó darle un fuerte apoyo a la industria cinematográfica nacional y acercar el cine mundial al público argentino. La elección de la ciudad sede se decidió por ser un destino turístico por excelencia, y fueron 18 los países representados por los 52 largos y 49 cortometrajes que se proyectaron. El presidente Perón fue el encargado de la inauguración del denominado Festival Cinematográfico Internacional que, tomando como modelo el de Venecia, pretendía acercar a las grandes estrellas de entonces al público argentino. 


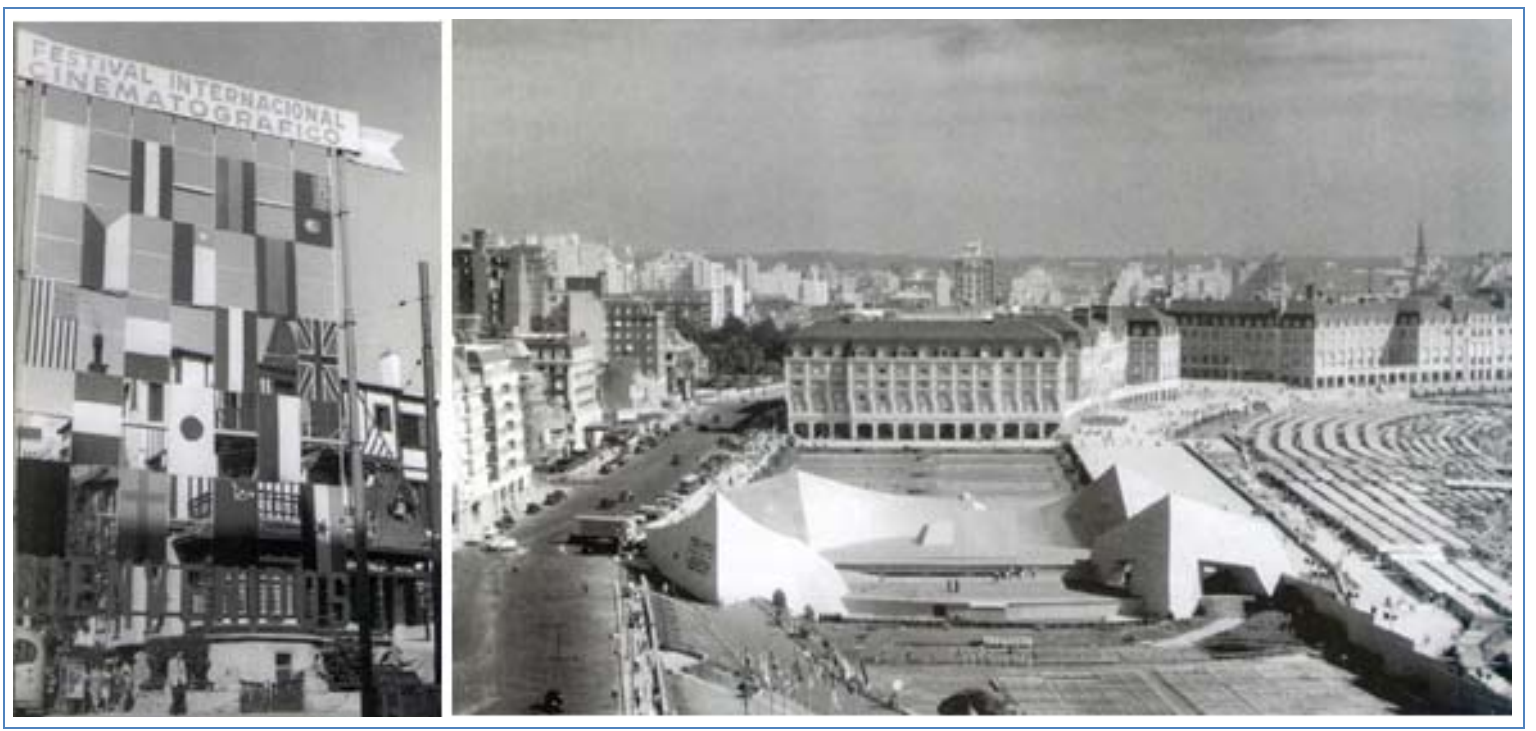

Figura 5a: Fotografías de las escenografías para El Festival Internacional de Cinematografía de Mar del Plata, 1954 | Fotografias do cenário para o Festival Internacional de Cinema de Mar del Plata, 1954 (Mosaico gráfico elaborado por el autor. Cortesía del Archivo Gráfico del CEDODAL y del Instituto de Inv. Hist. Eva Perón. Edición y corrección de imagen: Augusto Marchionni).

Los tres ejes propuestos -el histórico/político, el social/asistencial y el artístico/cultural-condensan cuestiones aparentemente diversas pero que incluyen una serie de fenómenos, todos ellos vinculados al sostenimiento del régimen y la construcción de su imaginario, que se propone señalar más tarde en el contexto de la Fiesta de la Vendimia. Es notable -a partir de reflexionar sobre todo en la profusa obra de gobierno del primer período- el poder y la efectividad que condensó la propaganda oficial con del uso de la prensa y los afiches publicitarios oficialistas. Esta formidable efervescencia que presentó el primer periodo de gobierno también tuvo -como veremos más adelante- su impacto en las resoluciones escenográficas de los años peronistas, con la particularidad de no ser automática sino diferida en el tiempo. En otras palabras, la profusión de actos e imágenes construidas en el primer período de gobierno tendrán su correlato material pocos años más tarde en la Fiesta de la Vendimia. 

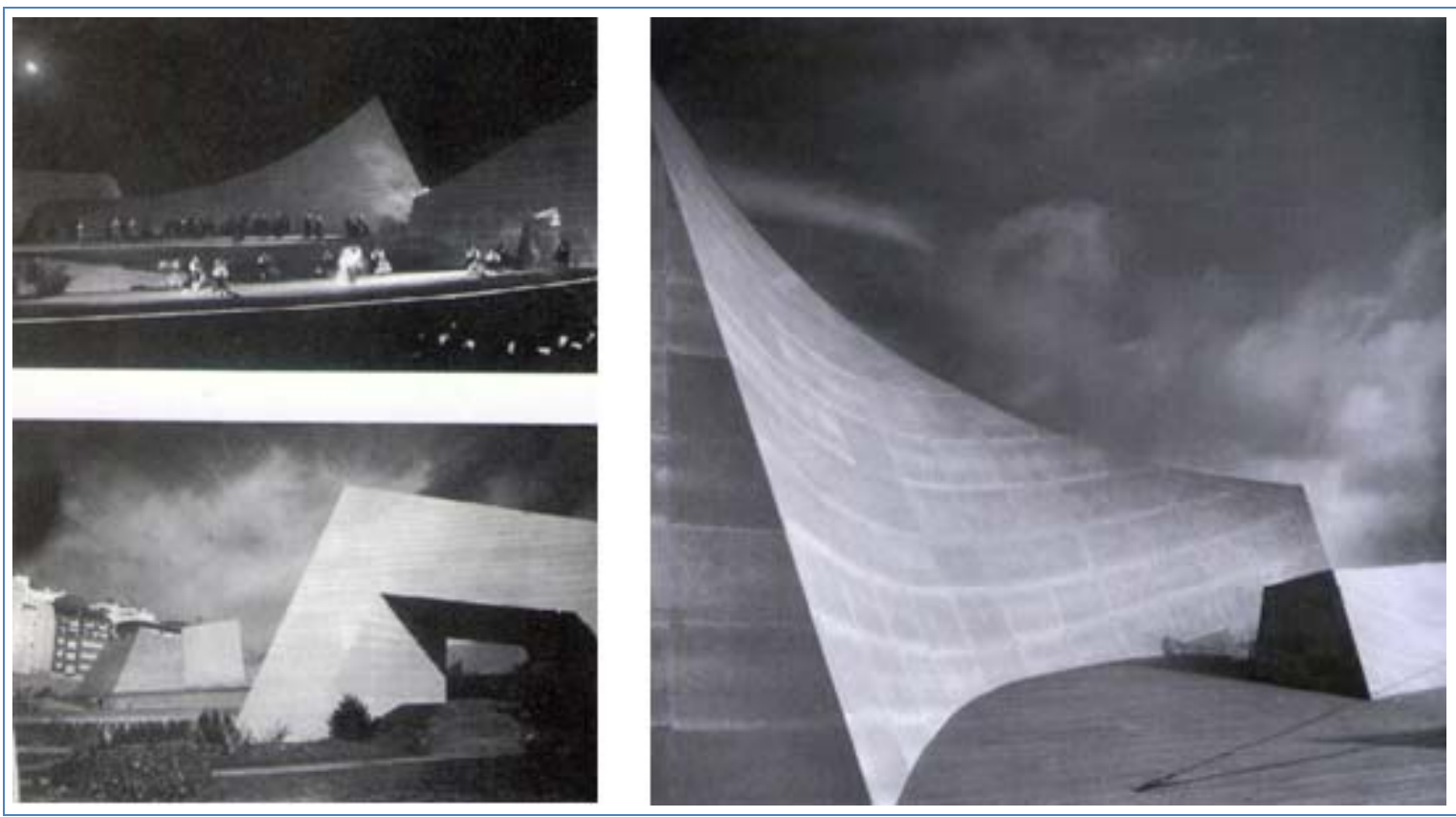

Figura 5b: Fotografías de las escenografías para El Festival Internacional de Cinematografía de Mar del Plata, 1954 | Fotografias do cenário para o Festival Internacional de Cinema de Mar del Plata, 1954 (Mosaico gráfico elaborado por el autor. Cortesía del Archivo Gráfico del CEDODAL y del Instituto de Inv. Hist. Eva Perón. Edición y corrección de imagen: Augusto Marchionni).

\section{Las fiestas de las economías regionales}

En ciertos asuntos la expansión de la actividad agroindustrial producida a fines del siglo XIX impulsado por el incremento del consumo y la protección estatal -como la industria vitivinícola en Mendoza- se conjugaron con estas fiestas para dar respuesta desde lo arquitectónico-escenográfico a esa voluntad política que buscaba legitimarse también en contextos festivos y populares.

En el caso de la Fiesta de la Vendimia, la belleza femenina fue puesta en competencia en las fiestas que se realizaron en diferentes pueblos y ciudades asociadas con una actividad productiva. Una mujer bella era coronada cuando se realizaban las fiestas de la vendimia, de la zafra azucarera, del tabaco, de la flor (Lobato, M., 2005). Las calles y plazas de distintos lugares del país se convirtieron en escenarios de diferentes festividades asociadas con la participación popular y el entretenimiento. 
Las fiestas del trabajo vitivinícola impulsadas por productores rurales e industriales, comerciantes y gobiernos locales -sobre todo en el contexto político del peronismo- promovieron e impulsaron un amplio desarrollo de los productos de la región de Cuyo. Estas fiestas se promovieron como parte de una política de creación, difusión e internalización de símbolos y fechas conmemorativas que utilizaba una amplia variedad de materiales significantes como objetos, eslóganes, exposiciones de productos regionales de cada área del país, publicaciones, películas y noticieros (Marchionni, F., 2008, 2012a, 2012b, 2013; y Sevilla, Ariel y Fabián, 2006).

Si bien no se consideró, en principio, las dificultades técnicas que hubo que resolver en torno al tema de la creación, si se puso énfasis en definir a qué cuestiones respondieron las soluciones escenográfico-espaciales adoptadas en el período considerado. Se trata más exactamente de reflexionar sobre las representaciones sociales y espaciales que surgieron del conjunto de proyectos que tanto los artistas como los técnicos de las instituciones oficiales articularon durante este período y qué grado de correspondencia tuvieron en relación con su contexto de producción.

Las condiciones sociales y políticas nacionales del período considerado permitieron pensar la Fiesta de la Vendimia en el contexto nacional junto a otras fiestas regionales y políticas -17 de octubre y $1^{\circ}$ de mayo- promovidas y ampliamente utilizadas por la administración peronista.

El primer aspecto desarrollado en este segundo apartado -el de las fiestas regionales- se refiere al vínculo que constituye nuestro interés, técnica y representaciones sociales. Éste se pretende abordar tanto desde la dimensión simbólica como desde la dimensión material. Es pertinente aclarar, desde el punto de vista de la historia de los escenarios vendimiales, que el peronismo se presentó como un corte radical, como el gobierno iniciador y promotor de los denominados “Palcos Monstruos", aunque sea necesario acudir al examen histórico del período del 1936 al 1945 para matizar y precisar esta aseveración. Finalmente, en el mismo sentido, pero cambiando la perspectiva hacia la historia de la técnica, podemos inferir que la inercia generada por los arquitectos a nivel nacional, que insistían en la necesidad de la intervención del Estado en la vivienda masiva, pudo haberse reflejado en la efectiva participación que estos tuvieron 
en la materialización de las escenografías de la década del 1950. Desde este punto de vista, el peronismo en el poder concedió un nuevo espacio creativo a los técnicos y, de este modo, logró perpetuarse en la historia de la fiesta promoviendo un imaginario técnico que llegó hasta nuestros días (Cf.: Marchionni, F., 2012b).

El segundo aspecto de la relación técnica/representaciones sociales se refiere a la estética arquitectónica, sobre todo interesa indagar en las formas visuales e imágenes que la administración peronista empleó para identificarse. Para ello, se apeló a interrogar de qué manera una producción técnica puede constituir una "estética de la política". ${ }^{4}$ En este sentido, se toma como punto de partida una observación de Manfredo Tafuri, según la cual la arquitectura promovida por el Estado no puede ser entendida como una derivación de la política, sino que demanda su consideración en tanto punto de articulación de propuestas políticas y técnicas (1995, p. 7); dicho de otro modo, la política no crea formas, sino que resignifica las existentes.

\section{Sondeos y evidencias}

La Fiesta de la Vendimia funcionó -y aún hoy funciona- como un gran espacio de “negociación” en el cual se despliegan estrategias, conflictos, intereses y posturas políticas, sociales y culturales (Cf.: Marchionni, F., 2012b). Más allá del festejo de un proceso productivo, esta fiesta se entiende como un fenómeno capaz de generar imágenes, íconos, patrones de belleza, mitos y modos de operar que configuran la identidad de Mendoza y es susceptible de ser reapropiada.

Antes de entrar en el análisis de los escenarios de las fiestas de 1946 y 1947, resulta conveniente presentar lo expresado por Le Corbusier en su trabajo Vers une Architecture de 1923, cuando afirma que:

\footnotetext{
${ }^{4}$ La expresión "estetización de la política" fue empleada inicialmente por Walter Benjamin con referencia al fascismo en su Theorien des deutschen Faschismus. Sin embargo, como demuestran trabajos como el coordinado por Maurizio Vaudagna (L'estetica della politica. Europa e America negli anni Trenta VII-XIV), el énfasis en la estetización de la política no se restringió a los gobiernos totalitarios, como lo demuestra la producción de los Estados Unidos en los años 1930. Una discusión sobre este tema puede verse en la "Introducción". Véase también Sandro Searrocchia ("Mefisto o la arquitectura del totalitarismo", pp. 5463).
} 
La arquitectura está más allá de los hechos utilitarios. La arquitectura es un hecho plástico. [...] La arquitectura es el juego sabio, correcto, magnífico de los volúmenes bajo la luz. [...] La arquitectura es arte en su sentido más elevado, su significado y su tarea no es sólo reflejar la construcción y absorber una función [...] (1923, p. 13).

A partir de estas reflexiones se podría agregar que la arquitectura implica además la idea de representación. Se consideran útiles para los propósitos de este trabajo las definiciones aquí planteadas, las cuales articulan la arquitectura con la plástica, la luz, el arte y la posibilidad de portar un significado. De ahí la pertinencia de su legado para abordar el objeto de estudio, el cual implicó un análisis arquitectónico y simbólico apostando a la observación y valoración de aspectos descriptivos. Esta labor estuvo sin dudas apoyada en la consideración del marco histórico y la atención del contexto social, económico y cultural de los objetos escenográfico-arquitectónicos.

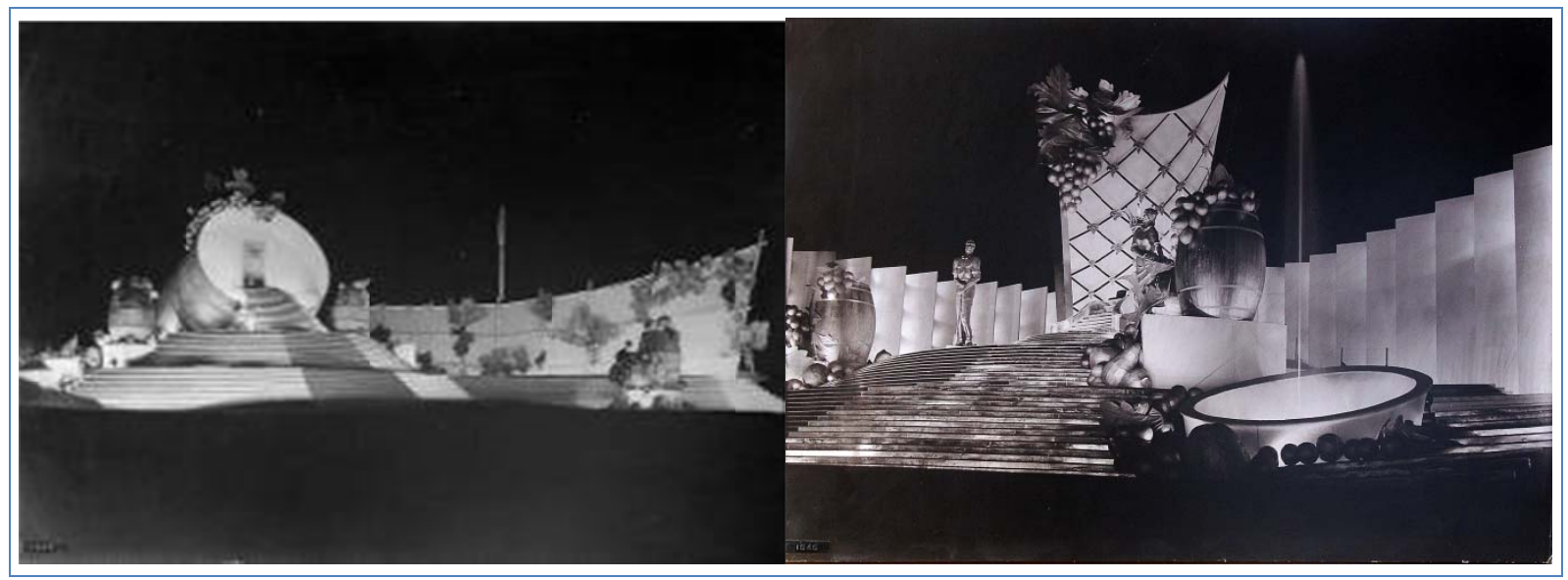

Figura 6: Fiesta de la Vendimia Acto Central de 1946 y 1947 | Evento principal da Festa da Vendimia de 1946 e 1947. (Mosaico fotográfico elaborado por el autor. Cortesía de Archivo Gráfico Colección The Sportman y Archivo Gráfico Diario Los Andes. Tomada de Sevilla, Ariel y Fabián. La Vendimia para Ver. 70 años de fiesta en 850 imágenes. Mendoza: Ministerio de Turismo y Cultura-Gobierno de Mendoza, 2006, pp. 35-36).

Los escenarios considerados en este período histórico presentan una escala acotada a los elementos formales utilizados para su resolución físico-espacial. A su vez, invocan un repertorio de elementos tradicionales vinculados al universo simbólico de la fiesta y el trabajo como son: los toneles, las viñas, la vid, el agua, el trabajo de los hombres y la belleza de las cosechadoras, la cual tiene un lugar de privilegio en los 
escenarios considerados. En su conjunto apelan al uso de un lenguaje formal apoyado en imágenes, íconos y atributos tradicionales vinculados al imaginario vendimial.

El escenario de la fiesta del 1946 tuvo como una de las principales características la utilización de la luz negra en el espectáculo. Este recurso de gran relevancia escenográfica le otorgó a la propuesta una caracterización tan particular que trascendió hasta nuestros días. El escenario era ovalado y con un gran tonel en el fondo que hacía de trono (Véanse Figura 6 a la izquierda).

Sin dudas, el 1947 constituye un año particular en el recorte temporal considerado en este trabajo por muchas razones. Entre las más destacadas nos corresponde citar la participación de Eva Perón -una figura controvertida- quien desarrolló un amplio conjunto de actividades sociales, políticas y estratégicas en orden a los intereses del régimen.

El principal acontecimiento de la Fiesta de la Vendimia -el Acto Central- se desarrolló en la Rotonda del Parque General San Martín la noche del 10 de abril de 1947. La dirección del espectáculo artístico en el contexto de la fiesta estuvo a cargo de León Alberti y la propuesta se denominó "Vendimia del Canto y El Trabajo". Para ello, se dispuso un escenario de enormes dimensiones inspirado en el cuento "Las mil y una noches" el cual cubría una superficie de $1.700 \mathrm{~m} 2$, tenía ascensores internos para los artistas, y el respaldo del trono se elevaba 23 metros sobre el tablado principal (Véanse Figura 6 a la derecha).

En la observación de los casos propuestos se verifica un foco central y escenarios o plataformas laterales que alojan a los figurantes. Este foco central gana en altura y condensa en todos los casos el trono de la reina. Las escalinatas, como elemento arquitectónico relevante, resultan protagonistas importantes y configuran y enmarcan el espacio. 


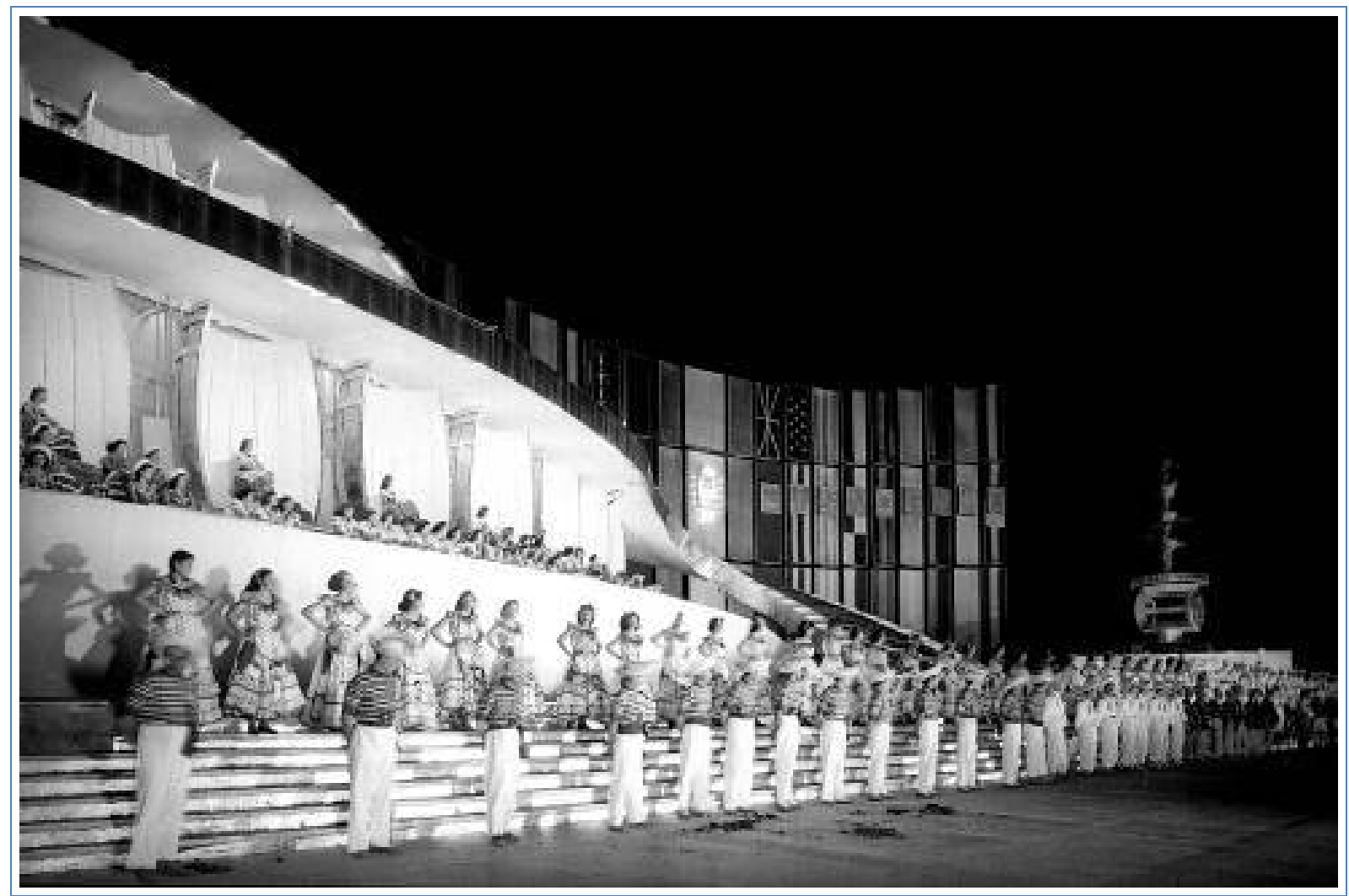

Figura 7: Fiesta de la Vendimia Acto Central de 1954 | Evento principal da Festa da Vendimia de 1954. Cortesía de Archivo Gráfico CGPG (Coordinación General de Prensa de la Gobernación de la Provincia) y Archivo Gráfico The Sportsman. Tomada de Sevilla, Ariel y Fabián. La Vendimia para Ver. 70 años de fiesta en 850 imágenes. Mendoza: Ministerio de Turismo y Cultura-Gobierno de Mendoza, 2006, p. 55.

La fiesta de 1954 se materializó de modo particular en coherencia con las líneas de pensamiento que venía instaurando el poder político en varios aspectos estratégicos. Así la fiesta de ese año retomó la idea pregonada por el peronismo que pensaba a la Argentina no como un nacionalismo "encajonado", en palabras del Presidente, sino que debía pensarse en "armonía" con sus vecinos latinoamericanos. El show "Canto a Mendoza" fue dirigido por Ivo Pelay y propuso una reconstrucción histórica de un periodo temporal que iba desde la época de la conquista hasta la lucha por la independencia de nuestro país. Para este cometido utilizó un repertorio de bailes y canciones del continente americano. 


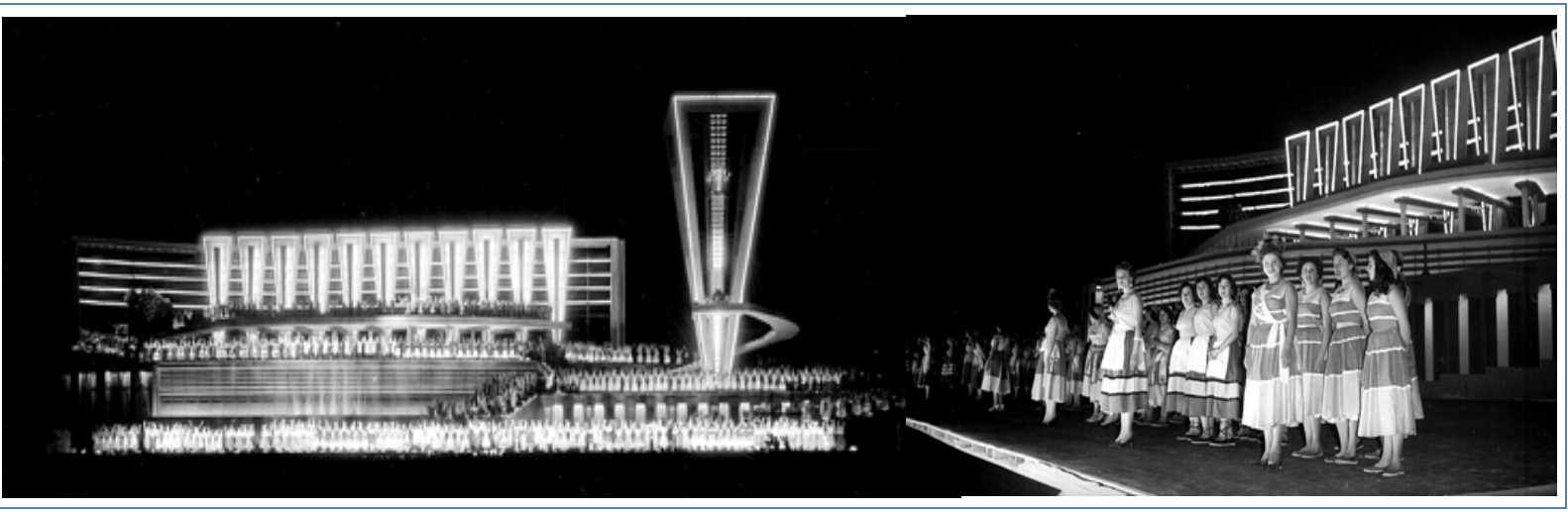

Figura 8: Fiesta de la Vendimia Acto Central de 1955 | Evento principal da Festa da Vendimia de 1955. Mosaico fotográfico elaborado por el autor. Cortesía de Archivo Gráfico CGPG (Coordinación General de Prensa de la Gobernación de la Provincia). Tomada de Sevilla, Ariel y Fabián. La Vendimia para Ver. 70 años de fiesta en 850 imágenes. Mendoza: Ministerio de Turismo y Cultura-Gobierno de Mendoza, 2006, p. 56.

El principal acontecimiento de la Fiesta de la Vendimia -el Acto Central- se desarrolló en el Autódromo del Parque General San Martín la noche del 12 de marzo de 1955. El espectáculo artístico se denominó “Homenaje a las vendimias y a las parras", en el cual bailaron empleados de comercio, estudiantes y bailarines de la Universidad Nacional de Cuyo, y en la exposición se plasmaron estampas de países productores de vino. No hubo línea argumental. Para ello, se dispuso un escenario de enormes dimensiones, de líneas arquitectónicas modernas y de un particular y distintivo contraste entre el lenguaje formal y estético de los figurantes del espectáculo y el marco arquitectónico efímero (Véanse Figura 8).

La modernización reflejada en estos Escenarios monumentales, lejos de ser un proceso que contribuyó con la extinción de las culturas autóctonas, más bien permitió en el contexto de la Fiesta de la Vendimia de la administración peronista- y hasta propició la reestructuración y reelaboración constantes de los elementos que conforman la cultura para el pueblo. Adicionó nuevos componentes que la nutrieron, la renovaron y le dieron vida, con lo que la identidad cultural del pueblo de "la nueva Argentina" se reafirmó y reconstruyó en un proceso de reinvención de símbolos y rituales como mecanismo destinado a la generación de consenso como fuente de legitimidad y refuerzo tanto de la imagen carismática de Perón como de su doctrina. El escenario del Acto Central de la Fiesta de la Vendimia de 1955 se desarrolló a partir de una propuesta que implicó el uso de una escala monumental. Estaba organizado espacialmente a partir de un foco principal a 
la derecha del escenario materializado por una pirámide invertida de enormes proporciones y, a la izquierda, el resto de los elementos de la composición a modo de contrapunto. La propuesta escenográfica puede analizarse rápidamente distinguiendo cinco componentes: la pirámide invertida que contiene el trono real y la corona, funcionando como foco de la composición; la repetición de once elementos en forma de triángulo invertido, el bastidor de fondo con marcadas líneas horizontales que dan sostén a los elementos anteriores; los planos horizontales de los tablados unidos por rampas y escaleras que le dan continuidad; y la gran masa de figurantes que refuerza la imagen de horizontalidad haciendo de contrapunto a la verticalidad del foco (Marchionni, 2012,p. 260).

La característica distintiva de este escenario radica, por un lado, en la monumentalidad expresada en la escala de los elementos de la escenografía y el contraste de esta con la masa de figurantes. Y por otro lado, en el uso del lenguaje de la arquitectura moderna con elementos geométricos simples desvinculados totalmente del repertorio alegórico utilizado en los escenarios de la década anterior.

Las escenografías del período del 1954 y 1955, que condensaban un lenguaje particularmente moderno, son conocidas en la historia de la fiesta como Escenarios monumentales en cuanto a la valoración de su escala arquitectónica y valor estético. Ostentan una significación ligada a la disciplina arquitectónica y aún hoy, con el paso del tiempo, conservan un sentido particular. Dichos escenarios pueden leerse además como una respuesta o emergente en función de la arquitectura local reproducida por el poder y la ideología del Estado. La evolución de la Fiesta de la Vendimia y la escenografía que la representa genera diversos interrogantes. Si bien ha ido adquiriendo mayor presencia urbana, su permanencia como fenómeno artístico y expresión colectiva del imaginario social de cada época no siempre resulta coherente con el espacio urbano / arquitectónico que lo contiene ni con el espacio rural / vitivinícola que lo sustenta. Paralelamente, cabe subrayar que más allá de su intención representativa de la Fiesta de la Vendimia, la escenografía, al igual que la arquitectura oficial, puede leerse como un modo de transmisión de valores socioculturales y, a su vez, como género de expresión colectiva. Puede servir además para preservar la memoria como base de nuestra identidad. Así 
planteada la cuestión escenográfica, podemos explicar esta puesta en escena de lo cultural y el papel que esta interpreta al mostrar lo que "es".

El debate aquí presentado, provisional y transitorio, da cuenta de la indispensable e imprescindible funcionalidad que a nivel metodológico, como de recurso explicativo, tienen las representaciones y los procesos simbólicos en la compresión del desarrollo y la estructuración de cualquier tipo de organización social. Nuestro trabajo propone transitar una de las vías de entrada que las ciencias sociales han abierto en relación con el tema de los imaginarios, los rituales políticos y las artes, en los que los procesos representativos cumplen un papel distintivo. ${ }^{5}$

Queda claro entonces el papel que estuvieron jugando tanto las fiestas regionales como las fiestas políticas y politizadas en el contexto cultural del peronismo y quienes eran los actores de tan original espectáculo. El lugar de Mendoza en el contexto nacional, su prominente economía regional, su posición estratégica y la disponibilidad de recursos energéticos hacían de la provincia un objeto de deseo en el proyecto político de Perón. Ese deseo político se valió de la fotografía, los afiches y de la arquitectura efímera para representar y materializar "su” revisión de la historia y así construir un particular relato histórico. Frente a este cuadro descriptivo no es desacertado pensar que la Fiesta de la Vendimia -ya para entonces consolidada- era un escenario privilegiado para promover conquistas políticas y sociales, razón por la cual concentraron el interés presidencial. En nuestro caso de estudio, entendemos estas manifestaciones culturales como parte destacada del aparato de propaganda peronista. Así la Fiesta de la Vendimia se transformó en testigo de varios de los valores promovidos desde la oficialidad y funcionó dentro de una red -amplia y compleja- de preceptos culturales y de poder. Esos escenarios funcionaron al interior del proyecto político, como productores de significados culturales, lugares de construcción y disputa de los mismos y además como cruce de diferentes cuestiones locales y nacionales (Marchionni, 2012, pp. 69-71).

\footnotetext{
${ }^{5}$ Para el caso de los imaginarios sociales una referencia básica se encuentra en Los imaginarios sociales. Memorias y esperanzas colectivas, de Bronislaw Baczko. Para el caso de los rituales y su relación con el poder y la estructuración social cabe recordar aquí la vía que va de la tradición antropológica originada en la Escuela de Manchester de Max Gluckman, pasando por Victor Turner y llegando incluso a las orientaciones francesas de George Balandier y Marc Auge quienes dedicaron sus investigaciones a la comprensión de sociedades complejas.
} 


\section{Ensayando algunas respuestas}

La teoría general de los imaginarios presenta matices, pliegues, intersticios que merecen ser revisitados. Las estructuras y métodos de aproximación a estas particularidades no deven ser usadas como fórmulas, modelos o categorías estrictas en su aplicación. En el abordaje de la fotografía como archivo privilgiado se busca ser más propositivo que impositivo. Frente a este postulado apuntamos que las fuerzas políticas, culturales y productivas identificadas, desde nuestra perspectiva, fueron capaces de construir representaciones sociales e imaginarios en clave efímera, mediadas por el poder político en función de un proyecto de país. Generaron imágenes, fotografías, escenarios y sintetizaron "recuerdos" con la intención manifiesta de capturar esa realidad presente, hoy pretérita, para favorecer la construcción del imaginario peronista. Señalamos además que estas expresiones efímeras -que circulaban por todo el país, con formatos diversos y detentando un enorme poder de difusión dado por el aparato del Estado- encontraron en el lenguaje arquitectónico moderno un medio coherente para comunicar el proyecto político que encarnó “la nueva Argentina”. La mixtura de la visión del país forjada por el peronismo y el imaginario común reflejado por la Fiesta de la Vendimia origina una síntesis que da origen a obras nuevas, creativas, imaginativas, que echan luz sobre la realidad de ese momento histórico a partir de la creación escenográfica inscripta en un modernismo pretendidamente latinoamericano. No obstante, queda demostrado que tanto los afiches de propaganda política como los fenómenos arquitectónicos efímeros señalados y descriptos en este trabajo funcionaron como soporte de luchas identitarias y políticas. La influencia del Estado en la conformación de estas expresiones fue significativa, sin embargo, su acción debió complementarse en el juego con otros actores y otras circunstancias (Marchionni, 2012, p. 321).

Plantear estos matices de la gestión peronista a partir de la confrontación entre el discurso y los hechos, no sólo es necesario sino que resulta un ejercicio intelectual indispensable, estimulante y enriquecedor, para recorrer críticamente los laberintos del complejo pasado argentino y contribuir a matizar sus explicaciones más allá de los mitos que, con extraordinaria fuerza histórica, envuelven y a veces distorsionan y uniforman la interpretación de los hechos. Conciliar lo fáctico y lo simbólico, distinguir -a la luz del 
juicio crítico- lo mítico y lo real que la memoria colectiva tiende a fusionar, confundir o parcializar, pretende ser nuestro aporte, siempre parcial, para rescatar las no linealidades, las complejidades y la pluralidad de opciones a partir de las cuales se configuró la Fiesta de la Vendimia de la década peronista.

Esta propuesta se cierra ensayando algunas respuestas en torno de los interrogantes planteados al inicio de este itinerario. En el balance analítico de este primer enfoque -que implicó la consideración de algunos aspectos políticos, sociales y culturales vinculados a las vendimias entre 1946 y 1955- convenimos en que es posible matizar la definición clásica de Weber, que considera al Estado como organización política obligatoria que demanda el monopolio del uso legítimo de la fuerza física dentro de su territorio (Weber, 1969), con la conceptualización de Bourdieu quien, por su parte, caracteriza al Estado moderno como una realización simbólica (1999, p. 195). La combinación de ambos elementos nos permite entender por qué las luchas históricas sobre el ejercicio de la energía simbólica estuvieron integradas a las luchas históricas sobre el ejercicio legítimo del poder militar, político y económico. Sin duda afirmamos que el escenario y el contexto de la Fiesta de la Vendimia fue también lugar de estas disputas. Las definiciones tradicionales del Estado moderno destacan la sutil relación entre los aspectos de la organización política, la jurisdicción territorial y el control sobre el ejercicio de la coerción. Gorski señala que los “estados son también pedagógicos, son organizaciones ideológicas" (2003, p. 165). ${ }^{6}$ Los sistemas de la educación primaria nacional, mientras tanto, imparten a sus estudiantes más que un plan de estudios un sustento estandarizado de conocimiento; las escuelas también introducen y naturalizan categorías fundamentales de la opinión, de los principios de la visión y de la organización social que permiten que la gente entienda a la sociedad y su lugar dentro de ella (Bourdieu, 1999; Hobsbawm and Ranger, 1983). Desde este punto de vista, afirmamos

\footnotetext{
${ }^{6}$ Para citar solamente algunos ejemplos bien conocidos que construyen y acumulan energía simbólica se pueden mencionar, entre otras, las actividades siguientes: realizar censos, relevar y confeccionar cartografía y construir museos (Anderson, 1991). De igual manera el desarrollo de registros civiles, de sistemas impositivos, de encuestas sobre la tenencia de la tierra, y otras estrategias que intervienen en la distribución y asignación de los recursos, en especial las regulaciones sobre el uso del suelo, y las intervenciones para promover o movilizar la radicación de población.
} 
que la Ley del Voto Femenino, el Primer Plan Quinquenal (1947-1951) ${ }^{7}$ y la promulgación de la Ley de Enseñanza Religiosa en Escuelas Públicas completaron y contribuyeron con la construcción del Estado de desarrollo en la Argentina. Afirmamos además,-como resulta evidente en el análisis propuesto, que estos acontecimientos tuvieron su repercusión en el contexto festivo de la vendimia.

El otro componente clave, de naturaleza simbólica, se aprecia en la política de difusión pública. La Secretaría de Prensa y Difusión generó un sustento de adhesión a las políticas públicas desconocido hasta ese momento. Con el establecimiento de innumerables prácticas administrativas como rutina, sobre todo aquellas enmarcadas en un macro plan de desarrollo y redistribución, el primer gobierno peronista sentó las bases del Estado de desarrollo en la Argentina. Esta práctica de naturaleza simbólica, en el caso particular de Mendoza, se vio además complementada y reforzada por los diversos actos que componen la Fiesta de la Vendimia. Desde esta perspectiva, se propone una discusión de las consecuencias que la construcción de la tradición escenográfica de la Fiesta de la Vendimia, su estructura de gestión y el correlato en la cimentación de los imaginarios sociales vinculados a este fenómeno han tenido en la formación y trascendencia de este período.

Los archivos entonces y sobre todo la gráfica y la fotografía del período consignado constituyen poderosos instrumentos para controlar lo que en el futuro se va a conocer del pasado. Estos reflejaron la particular dinámica de los hechos que le permitió a la administración peronista la acumulación de energía simbólica que se transformó en un refuerzo de la Identidad Nacional, tal como la conocemos hoy (Hobsbawm and Ranger, 1983). En consecuencia, debemos estar preparados para responder a los desafíos impuestos por el mundo contemporáneo y preservar su existencia y uso.

\footnotetext{
${ }^{7} \mathrm{Al}$ introducir la función de planificación de modo institucionalizado y permanente abre la puerta para que nuevos dominios de la actividad administrativa -algunos de los cuales registraban antecedentes transitorios, o, en todo caso, no legitimados por la práctica- se reconocieran como prácticas legítimas del Estado. Además, da lugar a una nueva configuración organizacional. De este modo, por ejemplo, para poder configurar el sistema de planificación se funda el Sistema Estadístico Nacional, para atender a los aspectos legales de una fuerte dinámica de ejecución, se crea el Cuerpo de Abogados del Estado y para atender a la población con un sentido universalista se elabora y aplica un Plan Nacional de Salud a todo el pueblo de la Nación. Este es el elemento de raíz weberiana (Weber, 1969).
} 


\section{Referencias}

Abric, Jean-Claude. (1994). Pratiques sociales et représentations. París: PUF.

Amaral, Samuel y Horacio Botalla. (2010). Imágenes del peronismo. Fotografías 1945-1955. Buenos Aires: UNTREF.

Anderson, Benedict. (1991). Imagined communities: reflections on the origin and spread of nationalis. London: Verso.

Baczko, Bronislaw. (1991). Los imaginarios sociales. Memorias y esperanzas olectivas. Buenos Aires: Nueva Visión.

Ballent, Anahí. (2005). Las huellas de la política. Buenos Aires: Prometeo / Universidad Nacional de Quilmes.

Barthes, Roland. (1986). El mensaje fotográfico. En: Lo obvio y lo obtuso. Imágenes, gestos, voces. Barcelona: Paidós, pp. 11-47.

Barthes, Roland. Retórica de la imagen. En: Lo obvio y lo obtuso. Imágenes, gestos, voces. Barcelona: Paidós.

Barthes, Roland. (1994). La cámara lúcida. Nota sobre la fotografía. Barcelona: Paidós.

Barros, Ana Taís Martins Portanova, Wunenburger, J.-J. (2015). A fotografia como catalisador simbólico - Notas para uma hermenêutica da fantástica em imagens técnicas. Intercom (São Paulo. Online), 38, 39-59.

Benjamin, Walter. (2008). Sobre la fotografía. Valencia: Pre-Textos.

Berger, Peter L., \& Luckmann, Thomas. (1991). The social construction of reality. a treatise in the sociology of knowledge. New York: Penguin.

Bourdieu, Pierre. (1965). Un art moyen: Essai sur les usages sociaux de la photographie, Paris: Les editions de Minuit.

Bourdieu, Pierre. (1988). Espacio social y poder simbólico. En: Cosas Dichas. Barcelona: Gedisa.

Bourdieu, Pierre. (ed.). (1989). La fotografía: un arte intermedio. México: Nueva Imagen.

Bourdieu, Pierre. (1999). Meditaciones pascalianas. Barcelona: Anagrama. 
Breyer, Gastón. (2005). La escena presente. Teoría y metodología del diseño escenográfico. Buenos Aires: Ediciones Infinito.

Debord, Guy. (1967). La sociedad del Espectáculo. Buenos Aires: La Marca.

Derrida, Jacques. (1997). Mal de archivo. Una impresión freudiana. Madrid: Trotta.

Didi-Huberman, Georges. (2006). Lo que vemos, lo que nos mira. Buenos Aires: Bordes Manantial.

Durand, Gilbert. (1995). A imaginação simbólica. Lisboa: Edições 70.

Durand, Gilbert. (2002). As estruturas antropológicas do imaginário. São Paulo: Martins Fontes.

Foucault, Michel. (1969). La arqueología del saber. México D.F.: Siglo XXI, p. 5.

Gastaud, Carla Rodrigues, Souza, Cristiéle Santos. (2013, jan./jun.). Guardar para mirar, guardar para mostrar: acervos autorreferenciais, da gaveta ao museu. Revista Tempo e Argumento. (Florianópolis). 5(9), 46-65.

Geertz, Cliffortd. (1991). La interpretación de las culturas. Buenos Aires: Gedisa.

Gené, Marcela. (2005). Un mundo feliz. Imágenes de los trabajadores en el primer peronismo 1946-1955. Buenos Aires: Fondo de Cultura Económica y Universidad de San Andrés.

Gil Calvo, Enrique. (1991). Estado de Fiesta. Madrid: Espasa-Calpe.

Giunta, Andrea (2008). Vanguardia, internacionalismo y política. Arte argentino en los años sesenta. Buenos Aires: Siglo XXI

Gomes, Ângela de Castro (org.) (2011). Vargas e a crise dos anos 50. 3. ed. Rio de Janeiro: Ponteio.

Gorski, Philip S. (2003). The disciplinary revolution: calvinism and the rise of the state in Early Modern Europe. Chicago: University of Chicago.

Gutiérrez, Ramón, Méndez, Patricia y Cacciatore, Julio (Edit.). (2009). Jorge Sabaté. Arquitectura para la justicia social. Buenos Aires: CEDODAL-Instituto de Inv. Hist. Eva Perón. 
Hartog, François. (2006). Tempo e patrimônio. Varia História. (Belo Horizonte). 22(36), 261-273.

Hosbawm, Eric. (1983). Inventando tradiciones. Cambridge: Cambridge University Press.

Hosbawm, Eric. (1992). Nación y nacionalismo desde 1780. Barcelona: Crítica.

Hovarth, Laszlo (comp.). (1993). A half century of peronism, 1943-1993. An international bibliography. Stanford: Hoover Institution-Stanford University.

Indij, Guido. (2006). Perón mediante. Grafica peronista del periodo clasico. Buenos Aires: La Marca.

Jodelet, Denise. (1984). La representación social: fenómenos, conceptos y teoría. En: Moscovici, S. Psicología social II. Pensamiento y vida social. Psicología social y problemas sociales. Barcelona: Paidós.

Jodelet, Denise. (1989). Représentations sociales: un domaine en expansion. En: D. Jodelet (Ed.). Les représentations sociales. París: PUF.

Le Corbusier. (1923). Hacia una Arquitectura. Barcelona: Ediciones Apostrofe.

Lima Vasconcellos, Felipe de Sousa. (2012, jan./jun.). Vargas e sua herança: a importância de se discutir a década de 1950 e a obra de Ângela de Castro Gomes. [Resenha GOMES, Ângela de Castro (org.). Vargas e a crise dos anos 50. 3. ed.]. Tempo \& Argumento. Revista do Programa de Pós-Graduação em História - PPGH. (Florianópolis). 4(1), 194-196.

Lobato, Mirta (ed.) (2005). Cuando las mujeres reinaban. Belleza, virtud y poder en la Argentina del siglo XX. Buenos Aires: Biblos.

Luna, Felix. (1984). Perón y su tiempo. La Argentina era una fiesta 1946-1949. Buenos Aires: Sudamericana.

Luna, Felix. (1985). Perón y su tiempo. La comunidad organizada 1950-1952. Buenos Aires: Sudamericana.

Luna, Felix. (1986). Perón y su tiempo. El régimen exhausto 1953-1955. Buenos Aires: Sudamericana.

Marchionni, Franco. (2008). Las Escenografías del Poder. El imaginario festivo y el poder político en imágenes, íconos y representaciones de la Fiesta Nacional de la Vendimia del 
primer peronismo. Revista F@ro (Valparaiso).7 (1). Recuperado el 24 octubre 2015, de http://web.upla.cl/revistafaro/02_monografico/07_marchionni.htm

Marchionni, Franco. (2010). Arquitectura en Vendimia. Sus Referentes Espaciales e Imaginarios Fundacionales 1964-1993. Mendoza: Zeta Editores.

Marchionni, Franco. (2012a). Arquitectura efímera, imaginario y fiesta. Saarbrücken: Editorial Académica Española.

Marchionni, Franco. (2012b). Arquitectura Efímera, rituales y fiesta. "Una historia social, cultural e imaginaria del espacio escenográfico de la vendimia 1913-1955" ANDINAS. Revista de estudios culturales. (San Juan, Arg.), 1(2), 64-77. ISSN 2250-493

Marchionni, Franco y Romina Sales. (2013). Paisajes del interior argentino: algunos testigos arquitectónicos del peronismo productivo de 1954 en clave moderna. Revista AS Arquitecturas del Sur, 43, 58-67. ISSN 0716-2677

Marx, Ursula, Schwarz, Gudrun, Schwarz, Michael, Wizisla, Erdmut (eds.). (2010). Archivos de Walter Benjamin. Fotografías, textos y dibujos. Trad. de Joaquín Chamorro Mielke. Madrid: Círculo de Bellas Artes/Sociedad Estatal de Conmemoraciones Culturales.

Moscovici, Serge. (1979). El psicoanálisis, su imagen y su público. Buenos Aires: Huemul.

Pereira, Chrystian Wilson. (2012, jan./jun.). Manuscritos em sépia, imagens da miudeza: legados de Walter Benjamin. [Resenha MARX, Ursula; SCHWARZ, Gudrun; SCHWARZ, Michael; WIZISLA, Erdmut (eds.). Archivos de Walter Benjamin. Fotografías, textos y dibujos]. Tempo \& Argumento. Revista do Programa de Pós-Graduação em História - PPGH. (Florianópolis). 4(1), 167-201.

Pérez-Liñán, Aníbal. (2013). Silvia Diana Mercado. El inventor del peronismo: Raúl Apold, el cerebro oculto que cambió la política argentina. [reseña] América Latina Hoy, 65, 211225.

Perón, Juan Domingo. (1949). Palabras introductorias del Presidente Perón. Actas del Primer Congreso Nacional de Filosofía, Tomo I. Mendoza: Universidad Nacional de Cuyo.

Perón, Juan Domingo . (1950). La Nación Argentina. Justa, libre y soberana. Buenos Aires: Ed. Subsecretaría de Informaciones de Presidencia de la Nación.

Perón, Juan Domingo . (1973). La comunidad organizada. Buenos Aires: Ed. Cepe. 
Perón, Juan Domingo. (1992). Mensaje al Congreso de la Nación del $1^{\circ}$ de Mayo de 1950. En: Ramella, Pablo. Prólogo a la Segunda Edición, La Internacional Católica. Buenos Aires: Depalma.

Rose, Gilian. (2007). Visual methodologies. An introduction to the interpretation of visual materials (2nd Edition). London: Thousand Oaks; New Delhi: Sage.

Santos, Francisco, Barros, Ana Taís Martins Portanova. (2012). Incursões da propaganda no imaginário: revisitando o brainstorm. Sessões do Imaginário (Impresso). 28, 85-93.

Santos, Roberg Januário dos, Barros, Lucilvana Ferreira. (2013). A poética do espaço: a escrita e a produção da paisagem dos verdes carnaubais assuenses (1950-1970). Revista Tempo e Argumento. (Florianópolis). 5(9), 102-133.

Scarrocchia, Sandro. (2000). Mefisto o la arquitectura del totalitarismo. Block, 3, 54-63.

Scarrocchia, Sandro. (2013). Albert Speer e Marcello Piacentini. L'architettura del totalitarismo negli anni Trenta. Milan (second edition enlarged and corrected) http://www.skira.net/albert-speer-e-marcello-piacentini-6140.html

Scherer, Joanna. (1997). Documentos fotográfico: fotografias como dado primário na Pesquisa. Cadernos de Antropologia e Imagem. (Rio de Janeiro). 2(3).

Schwartz, Joan M., Terry Cook. (2002). Archives, records, and power. The Making of Modern Memory. Archival Science, 2, 1-19.

Sevilla, Ariel y Fabián. (2006). La Vendimia para Ver. 70 años de fiesta en 850 imágenes. Mendoza: Ministerio de Turismo y Cultura-Gobierno de Mendoza.

Silva, A. (1997). Imaginarios urbanos. Cultura y comunicación urbana. Buenos Aires: Tercer Mundo.

Silvia Mercado, Diana (2013). El inventor del peronismo: Raúl Apold, el cerebro oculto que cambió la política argentina. Buenos Aires: Planeta. 360 pp.

Smith, Shawn Michelle. (1999). Superficial Depths. En: American Archives. Gender, Race, and Class in Visual Culture. New Jersey: Princeton University Press. pp. 93-112.

Sturken, Marita. (1999). The image as memorial: personal photographs in cultural memory. En: Marianne Hirsch, (ed.). The familial gaze. Hanover: University Press of New England. 
Tafuri, Manfredo. (1995). Vienna Rossa. La politica residenziale nella Vienna socialista. Milano: Electa, p. 7.

Torre, Juan Carlos (comp.). (1995). El 17 de octubre de 1945. Buenos Aires: Ariel.

Turner, Víctor. (1967). La selva de los símbolos. Madrid: Alianza.

UNESCO. (2003). Convención para la salvaguardia del patrimonio cultural inmaterial. Paris.

Valles, Miguel. (2000). Técnicas cualitativas en investigación. Reflexión metodológica y práctica profesional. Madrid: Síntesis Sociología.

Vaudagna, Maurizio (a cura di). (1989). L'estetica della politica. Europa e America negli anni trenta. Roma-Bari: Laterza.

Villafañe, Justo. (1988). Introducción a la teoría de la imagen. Madrid: Pirámide.

Weber, Max. (1922). Economía y sociedad. México: FCE.

Recebido em 29/02/2016

Aprovado em 29/04/2016

Universidade do Estado de Santa Catarina - UDESC

Programa de Pós-Graduação em História - PPGH

Revista Tempo e Argumento Volume 08 - Número 17 - Ano 2016 tempoeargumento@gmail.com 